\title{
Scratch2 Prevents Cell Cycle Re-Entry by Repressing miR-25 in Postmitotic Primary Neurons
}

\author{
Eva Rodríguez-Aznar, Alejandro Barrallo-Gimeno, and M. Angela Nieto \\ Instituto de Neurociencias, CSIC-UMH, San Juan de Alicante 03550, Spain
}

During the development of the nervous system the regulation of cell cycle, differentiation, and survival is tightly interlinked. Newly generated neurons must keep cell cycle components under strict control, as cell cycle re-entry leads to neuronal degeneration and death. However, despite their relevance, the mechanisms controlling this process remain largely unexplored. Here we show that Scratch2 is involved in the control of the cell cycle in neurons in the developing spinal cord of the zebrafish embryo. scratch 2 knockdown induces postmitotic neurons to re-enter mitosis. Scratch2 prevents cell cycle re-entry by maintaining high levels of the cycle inhibitor p57 through the downregulation of miR-25. Thus, Scratch2 appears to safeguard the homeostasis of postmitotic primary neurons by preventing cell cycle re-entry.

\section{Introduction}

The mechanisms controlling the cell cycle, cell differentiation, and survival are tightly regulated during nervous system development to ensure that the correct number of neurons and glial cells are generated when required (Guillemot, 2007). Neuronal differentiation is tightly linked to cell cycle withdrawal (BallyCuif and Hammerschmidt, 2003), and it has been classically thought that neurons are locked in the postmitotic state. However, postmitotic neurons must actively retain the control of their cell cycle components to prevent the reversion to the proliferative state (Herrup and Yang, 2007; Devès and Bourrat, 2012). Inappropriate cell cycle re-entry is associated with cell death and indeed observed in a wide variety of pathological states, such as retinoblastoma and Alzheimer's disease and in the response to DNA damage (Kruman et al., 2004; Herrup and Yang, 2007; Varvel et al., 2009). Thus, not only is it crucial to understand the mechanisms that drive cell cycle exit but also those that prevent its re-initiation, events, which are less well understood.

Cyclin-dependent kinase inhibitors (CKIs) and the retinoblastoma proteins are involved in the maintenance of the postmitotic state (Sage et al., 2003; Ajioka et al., 2007; Laine et al., 2007; Pajalunga et al., 2007; Zhang et al., 2008). Therefore, it is

Received Sept. 19, 2012; revised Jan. 2, 2013; accepted Jan. 30, 2013.

Author contributions: E.R.-A. and M.A.N. designed research; E.R.-A. performed research; A.B.-G. contributed unpublished reagents/analytic tools; E.R.-A. and M.A.N. analyzed data; M.A.N. wrote the paper.

Work in the lab is supported by grants from the Spanish Ministry of Science and Innovation (BFU2008-01042, CONSOLIDER-INGENI0 2010 CSD2007-00017, and CSD2007-00023) and the Generalitat Valenciana (Prometeo 2008/ 049) to M.A.N. We are grateful to Diana Abad for excellent technical support in the fish facility, Giovanna Expósito for help with the confocal microscope, Stuart B. Ingham for his help with Figure 8 and video editing, and to all lab members for their helpful discussions. We also thank Oscar Marin, Isabel Fariñas, and Joan Galcerán for helpful comments on this manuscript.

The authors declare no competing financial interests.

Correspondence should be addressed to: M. Angela Nieto, Instituto de Neurociencias, CSIC-UMH, Avda. Ramón y Cajal s/n, San Juan de Alicante 03550, Spain. E-mail: anieto@umh.es.

A. Barrallo-Gimeno's present address: Departament de Ciències Fisiològiques II, Facultat de Medicina, Universitat de Barcelona, Campus de Bellvitge, L'Hospitalet de Llobregat, 08907 Barcelona, Spain.

DOI:10.1523/JNEUROSCI.4459-12.2013

Copyright $\odot 2013$ the authors $\quad 0270-6474 / 13 / 335095-11 \$ 15.00 / 0$ important to understand how the expression of CKIs is controlled both during and following neuronal differentiation.

Here we show that scratch2, a member of the Scratch family of transcription factors specifically expressed in the nervous system from Drosophila and Caenorhabditis elegans to vertebrates (Roark et al., 1995; Nakakura et al., 2001; Marín and Nieto, 2006; RodríguezAznar and Nieto, 2011) maintains high levels of the CKI family member p57 (cdkn1c), thereby preventing neuronal cell cycle reentry. As such, we show that scratch 2 knockdown induces proliferation in differentiated neurons by increasing the expression of miR25 , which in turn, decreases p57 levels abrogating its function in maintaining differentiated neurons in the postmitotic state.

\section{Materials and Methods}

Fish maintenance. Wild-type (WT) strains used in this work are $\mathrm{AB}$ and Tup-Lof zebrafish. The transgenic line $T g(h u C: G F P)$ was kindly provided by Elisa Martí. The transgenic line $T g(x E F 1 a: H 2 B-R F P)$ was generated using the xEF1a minimal promoter driving the expression of red fluorescent protein mRFP1 fused in frame to the sequence of zebrafish $\mathrm{H} 2 \mathrm{~B}$ histone. This construct was introduced into one-cell zebrafish embryos using the miniTol2 vector, a kind gift from J.L. Gómez-Skarmeta (Balciunas et al., 2006) and Tol2 transposase mRNA. Embryos were maintained at $28^{\circ} \mathrm{C}$ under standard conditions and staged as described previously (Kimmel et al., 1995)

Isolation of cDNAs and PCR. Total RNA was extracted from $24 \mathrm{~h}$ postfertilization (hpf) zebrafish embryos with Trizol (Invitrogen) and used as a template to synthesize cDNA with SuperScript III reverse transcriptase (Invitrogen) and oligodT as the primer. The following primers were used for $c d k n 1 c$ (NM 001002040) forward: 5'-ggatccgctcacggcattgactttta$3^{\prime}$ and reverse $5^{\prime}$-tctagatggactgatgtatgtatagtgcaaa-3'. The human $\mathrm{Mcm} 7$ intronic region containing the $\mathrm{miR}-106 \mathrm{~b} \sim 25$ cluster was amplified from human DMS53 cells genomic DNA, using the primers: forward, $5^{\prime}$-AT GGATCCCTGGAGGGCCATCTGTTTT-3'; ;everse, 5' -GGTCTAGAGT GCCTAAGGGGAAGGTAGG-3'. Amplified fragments were subcloned into pGEM.TE and pCS2+.

Morpholino oligonucleotides and mRNA injections. All morpholino antisense oligonucleotides were obtained from Gene Tools and used as described by (Nasevicius and Ekker, 2000). The following morpholino oligonucleotides (MOs) were used at 2 ng/embryo: scratch2 ${ }^{\mathrm{MO}} 5^{\prime}$-CGCA CCAGAAAATCCTTCACATCGG-3' located at the 5' UTR (described as 
Table 1. Primers

\begin{tabular}{lll}
\hline Gene & Forward primer $\left(5^{\prime}-3^{\prime}\right)$ & Reverse primer $\left(5^{\prime}\right.$ - $\left.3^{\prime}\right)$ \\
\hline Gapdh-AY818346 & TGCGTTCGTCTCTGTAGATGT & GCCTGTGGAGTGACACTGA \\
cdkn1c-NM_001002040 & CACATCCACGAGCATTGAAG & CCGCTCTGCAGATAAACAGA \\
mcm7-NM_212569 & GACTACATCACTGGGGGTA & GGATGGACAGCAGTGTCTG \\
scratch2 & As described previously (Rodríguez-Aznar and Nieto, 2011) \\
\hline
\end{tabular}

MO2 in Rodríguez-Aznar and Nieto, 2011) and miR-25 $5^{\mathrm{MO}} 5^{\prime}$-TGTCAG ACCGAGACAAGTGCAATGC- $3^{\prime} \cdot p 53^{\mathrm{MO}}: 5^{\prime}$-GCGCCATTTGCAAGA ATTG-3' was injected at $4.5 \mathrm{ng} / \mathrm{embryo}$ (Robu et al., 2007; RodríguezAznar and Nieto, 2011). The standard control morpholino from Gene Tools was used for the control injections. All oligonucleotides were injected into the yolk of one- or two-cell embryos using a pressure injector (PicoSpritzer). For rescue and overexpression experiments mRNA was synthesized and capped using the mMessage mMachine Kit (Ambion). Rescue analyses were performed with 75 pg/embryo of scratch 2 mRNA lacking the $5^{\prime} \mathrm{UTR}$ region to which scratch ${ }^{\mathrm{MO}}$ binds. For overexpression analyses $100 \mathrm{pg} / \mathrm{embryo}$ of control (red fluorescent protein, $\mathrm{rfp}$ ), $20 \mathrm{pg} /$ embryo of $c d k n 1 c$, or $200 \mathrm{pg} /$ embryo of $h s a-m i R 25$ mRNA were used.

In situ hybridization and immunohistochemistry. Antisense RNA probes were generated from plasmids containing sequences for the different genes. The scratch 2 probe has been described previously (Rodríguez-Aznar and Nieto, 2011). Plasmid containing the $h u C$ sequence was provided by M.J. Blanco, and those for islet1 (isl1), islet2 (isl2), pax $2 a$, and $n k x 6.1$ by A. Barrallo-Gimeno. For immunohistochemistry we used the primary antibodies against as follows: $\mathrm{pH} 3$ (rabbit anti-pH3 antibody, 1:1000; Millipore Biotechnology) HuC/D (mouse anti $\mathrm{HuC} / \mathrm{D}, 1: 1000$; Invitrogen), and green fluorescent protein (GFP) (rabbit anti-GFP, 1:1000; Invitrogen). The secondary antibodies used were biotinylated goat anti-mouse (1:1000; Vector Laboratories), biotinylated goat anti-rabbit (1:1000; Sigma), Alexa Fluor 568 goat anti-mouse, and Alexa Fluor 488 goat anti-rabbit (1/500) from Invitrogen. In situ hybridization and immunohistochemistry of whole-mount zebrafish embryos were performed as described previously (Acloque et al., 2008). The embryos were then fixed and embedded in gelatin to obtain vibratome sections $(30 \mu \mathrm{m})$. To visualize the nuclei, $1 \mu \mathrm{l}$ of $1 \mathrm{mg} / \mathrm{ml}$ Hoechst solution (bisbenzimide H; Sigma) was added on vibratome sections in $1 \mathrm{ml}$ of PBS. Embryos were photographed using an Olympus DP70 digital camera on either a Leica M10 dissecting microscope or a Leica DMR microscope. For fluorescently labeled embryos, confocal images were acquired using a Leica TCS SP2 AOBS confocal microscope.

Quantitative real-time reverse transcription PCR. Quantitative realtime reverse transcription PCR (qRT-PCR) was performed using the Step One Plus (Applied Biosystems) sequence detection system and the SYBR Green method. The data represent the mean of three independent experiments with each point analyzed in triplicate. Transcript levels were calculated using the comparative Ct method normalized to GAPDH. The final results were expressed relative to the control condition using the $2^{-(\Delta \Delta \mathrm{Ct})} \pm \mathrm{SD}$ formula. The primers used were as see in Table 1.

For mature dre-miR-25 detection, TaqMan PCR was performed using the TaqMan MicroRNA Cells-to-Ct Kit (Ambion) and hsa-miR-25 TaqMan MicroRNA Assays (Applied Biosystems) primers. The results represent the mean of at least three independent experiments \pm SD.

TUNEL assay. Apoptosis was analyzed using the TUNEL kit (Roche) incubated with the reagents according to manufacturer's instructions as described previously (Rodríguez-Aznar and Nieto, 2011).

Cell quantification. HuC/D- and $\mathrm{pH} 3$-positive cells were counted in consecutive sections ( $30 \mu \mathrm{m}$ thick) from embryos at $24 \mathrm{hpf}$ corresponding to five consecutive somites (s5-s9). Fluorescently labeled cells were counted in sections under the confocal microscope through $z$-scan. isllpositive cells were counted in $24 \mathrm{hpf}$ dorsal flat-mounted embryos. pax2a- and isl2-labeled cells were quantified in lateral flat-mounted embryos, in five hemisegments per embryo. Quantification of pax $2 a$ - and isl1-positive cells at the 16 somites stage spanned from s2 to $\mathrm{s} 6$.

Luciferase assays. To generate the luciferase reporter plasmids, a cdkn1c 3' UTR fragment (407 bp from nucleotide 41 after the TGA stop codon to nucleotide 29 before the polyA sequence) containing the predicted
miR-25 binding site was subcloned into the pGL3-promoter vector (Promega) downstream of the luciferase sequences. PCR amplification was performed on adult zebrafish genomic DNA as a template using the oligonucleotide primers 5' -GCAGAGCGGATGAAAGAAAG-3' and 5' GATTCAAAGGTACAACGTGAGC-3'. Luciferase assays were performed in zebrafish embryos as described previously (Alcaraz-Pérez et al., 2008). Briefly, the reporter plasmid of the firefly luciferase gene (25 $\mathrm{pg} / \mathrm{e}$ ) was injected into one-cell embryos, together with $2.5 \mathrm{pg}$ of a plasmid containing the Renilla luciferase gene under the control of the Tk promoter and the amount of the different MOs or mRNAs as described in MOs and mRNA injections. Twenty embryos of each experimental condition were lysed in $100 \mu \mathrm{l}$ of lysis buffer (Passive lysis buffer; Promega) and assays were performed on $10 \mu \mathrm{l}$ of the embryo lysate with a Dual-Luciferase Reporter Assay System (Promega). The data are represented as the mean $\pm \mathrm{SD}$ of three different experiments.

Live imaging and image processing. Transgenic embryos at $24 \mathrm{hpf}$ were dechorioned and anesthetized before being mounted in 1\% low melting point agarose in $35 \mathrm{~mm}$ glass-bottom culture dishes (MatTek). Images were taken on the Leica TCS SP2 AOBS inverted confocal microscope every $3 \mu \mathrm{m}$, every $2.5 \mathrm{~min}$ with the $40 \times$ objective plus $2 \times$ optical zoom. Images were then processed with the Imaris software version 7.0 to produce the videos. Twenty-four frames are shown over a region of $6 \mu \mathrm{m}$ (corresponding to three confocal planes) at 3 frames per second; 3D orthogonal representations of huC:GFP spinal cord vibratome sections show a $z$-stack of $18 \mu \mathrm{m}$ (seven confocal planes) using the Imaris software in Fib. 2B. Acquired images were further processed with Adobe Photoshop software to generate overlays.

Statistics. All values are presented as the mean \pm SD. All comparisons were performed using the Student's $t$ test for samples with unequal variance. Differences were considered statistically significant when $p<0.05$; ${ }^{*} p<0.05,{ }^{* *} p<0.01,{ }^{* *} p<0.001$.

Database searches. NCBI and EMBL-EBI/Wellcome Trust Sanger Institute databases were searched using the BLAST family of programs (http://www.ncbi.nlm.nih.gov/BLAST) and http://www.ensembl.org, respectively, and the http://www.mirbase.org/, used for zebrafish $c d k n 1 c$ miRNA target prediction.

\section{Results}

\section{Postmitotic neurons in the zebrafish spinal cord express scratch 2}

We previously demonstrated that zebrafish scratch genes are specifically expressed in the developing nervous system and that scratch 2 is the only family member prominently expressed in the spinal cord (Rodríguez-Aznar and Nieto, 2011). We have now characterized the scratch2-expressing cells and found that at 24 hpf, it is confined to the mantle layer in the spinal cord (Fig. $1 A, B)$. We could not find cells that coexpressed scratch 2 and the mitotic cell marker phospho-histone 3 (pH3) (Fig. 1B). Indeed double-labeling experiments at $24 \mathrm{hpf}$ indicated that scratch2expressing cells are neurons that express the postmitotic marker $h u C$ (Kim et al., 1996) and isll, which is considered a marker of early neuronal differentiation and is expressed in Rohon Beard (RB), primary interneurons (INs), and motoneurons (MNs) at the time of cell cycle exit (Korzh et al., 1993; Hutchinson and Eisen, 2006) (Fig. 1C). scratch2 transcripts persisted at $36 \mathrm{hpf}$, although at much lower levels, as signal was only detected after a much longer developing time (Fig. 1D). In summary, we find that scratch 2 is expressed in postmitotic spinal primary neurons.

\section{The number of postmitotic neurons increases following scratch 2 knockdown}

To understand the role of Scratch2 in neurogenesis, we disrupted its activity by injecting antisense MOs into one-cell zebrafish embryos. We previously used this strategy to demonstrate the importance of Scratch2 for the survival of spinal neurons and thus, the same experimental controls and conditions were used in this 


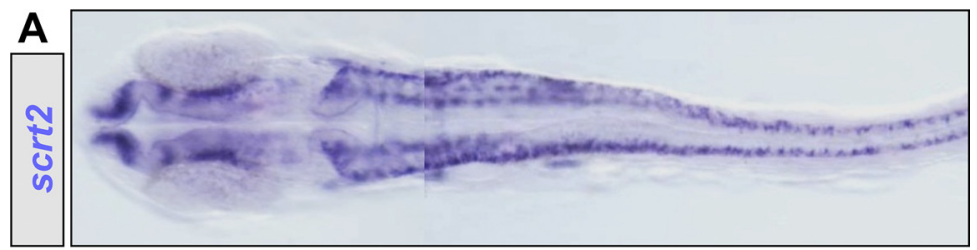

B
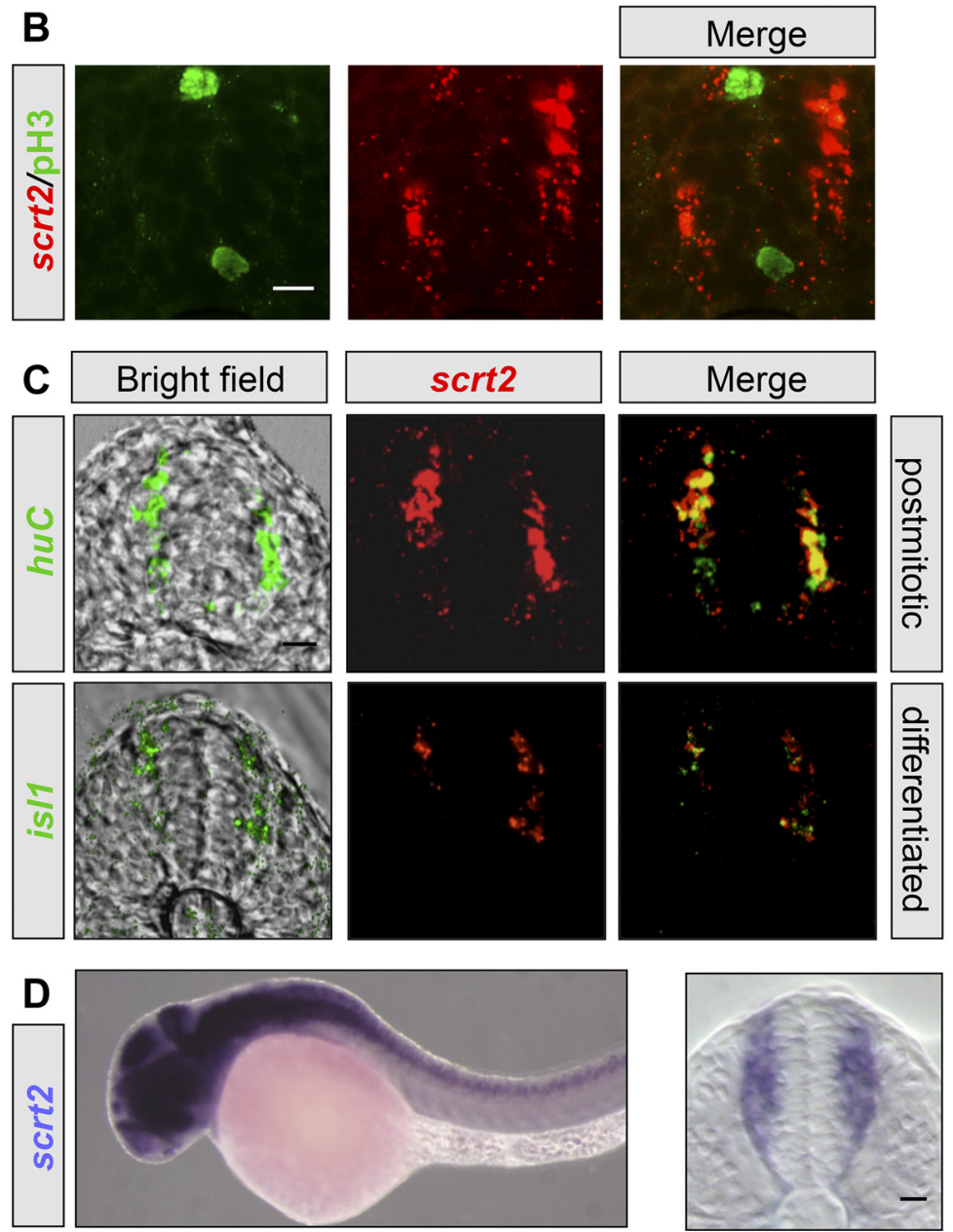

Figure 1. Expression of scratch2 (scrt2) in the spinal cord of $24 \mathrm{hpf}$ zebrafish embryos relative to that of other neural markers. $\boldsymbol{A}$, Expression of scratch 2 in a whole-mounted embryo at $24 \mathrm{hpf}$. $\boldsymbol{B}$, scratch 2 expression was not evident in mitotic cells revealed by pH3 staining in transverse sections at the mid spinal cord level. C, Coexpression of scratch2 with differentiation markers. scratch2 is shown in red, other genes in green, and colocalization in yellow in the merged images. The markers selected were huC (postmitotic) and is/1 (differentiated RB, primary INs and MNs). scratch2 colocalizes with both huC and is/1. D, scratch2 expression decreased in the $36 \mathrm{hpf}$ spinal cord compared with that at $24 \mathrm{hpf}(\boldsymbol{B})$. Embryo in $\boldsymbol{D}$ was overdeveloped to better assess expression in the spinal cord. Scale bars, $10 \mu \mathrm{m}$.

work (Rodríguez-Aznar and Nieto, 2011 and Materials and Methods). We next investigated whether scratch2 downregulation after morpholino injection affected the number of differentiating neurons by quantifying cells expressing $\mathrm{HuC} / \mathrm{D}$, used extensively as a general marker for postmitotic neurons (Park et al., 2000). This approach allowed us to assess the overall impact of scratch 2 knockdown on the entire postmitotic neuronal population. We found that scratch 2 morphants exhibited an increase in $\mathrm{HuC} / \mathrm{D}$-positive neurons compared with control embryos at 24 hpf (Fig. 2A). This effect was specific to scratch 2 loss of function, as coinjection of scratch $2^{\mathrm{MO}}$ with scratch 2 mRNA reversed the increase in $\mathrm{HuC} / \mathrm{D}$-positive neurons. scratch 2 knockdown also leads to an upregulation of the p53 effector puma leading to neuronal apoptosis, which in turn induces proliferation of

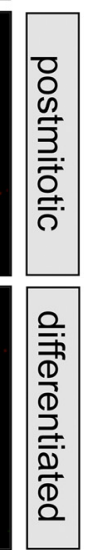

neural progenitors in the ventricular zone (VZ; Rodríguez-Aznar and Nieto, 2011). Therefore, we wondered whether compensatory proliferation of the progenitors could at least in part account for the neuronal hyperplasia phenotype observed in scratch 2 morphants. We coinjected scratch $2^{\mathrm{MO}}$ and $p 53^{\mathrm{MO}}$, as $\mathrm{p} 53$ inhibition prevents the cell death induced by scratch 2 knockdown (Rodríguez-Aznar and Nieto, 2011). As described, $p 53^{\mathrm{MO}}$ injection alone had no effect on embryonic development (Robu et al., 2007). Embryos coinjected with both scratch 2 and p53 MOs $\left(\right.$ scratch $\left.2^{\mathrm{MO}}+p 53^{\mathrm{MO}}\right)$ had more $\mathrm{HuC} / \mathrm{D}$ neurons like those injected with scratch $2^{\mathrm{MO}}$ alone (Fig. $2 \mathrm{~A}$ ). These results suggest that Scratch2 has an additional function in the control of neuronal number/differentiation independent from its role in promoting survival. To accurately quantify the increase in postmitotic neurons we analyzed serial confocal sections of scratch $2^{\mathrm{MO}}$-injected embryos from a $\mathrm{Tg}($ huC:GFP) transgenic line (Fig. 2B) and after fluorescent immunohistochemistry for $\mathrm{HuC} / \mathrm{D}$ (Fig. 2C), and observed that morphant embryos had 28\% more neurons than control embryos in both cases (Fig. 2D; data not shown). The same increase was also observed with or without coinjection of $p 53^{\mathrm{MO}}$ (Fig. $2 D$; data not shown). Thus, Scratch2 has a specific role in regulating the number of postmitotic neurons independently from its function in promoting neuronal survival.

\section{The number of spinal primary neurons} is controlled by Scratch2

In light of the data obtained, it was of interest to determine whether Scratch2 influenced the number of all spinal neurons or whether the increase in postmitotic neurons observed in the morphants was associated with specific populations. The neuronal subpopulations in the spinal cord of 24 hpf zebrafish embryos include primary sensitive or RB neurons, INs and primary MNs (Lewis and Eisen, 2003). These neurons can be identified by the expression of different markers: isl1 for RB, INs, and MNs (Korzh et al., 1993); pax2a for commissural IN (Pfeffer et al., 1998); and isl2 for RB and primary MN (Appel et al., 1995).

In scratch 2 morphants at $24 \mathrm{hpf}$ there was no change in the number of RB neurons identified by isll expression when compared with WT and controls (Fig. 3A; $6.15 \pm 0.24$ in WT and $6.2 \pm 0.53$ in scratch $2^{\mathrm{MO}}$ cells per somite, $n=7$ embryos per condition). The number of INs analyzed by pax $2 a$ expression did not change either (Fig. $3 B ; 4.03 \pm 0.78$ in WT and $4.08 \pm 0.46$ in scratch $2^{\mathrm{MO}}$ cells per hemisegment, $n=6$ ). In contrast, the number of isl2-positive MNs was increased after scratch $2^{\mathrm{MO}}$ injection (Fig. 3C,D; $1.94 \pm 0.18$ in WT and $4.67 \pm 0.6$ cells per hemisegment in scratch $2^{\mathrm{MO}}\left(p=1 \times 10^{-6}\right), n=6$ embryos in control 

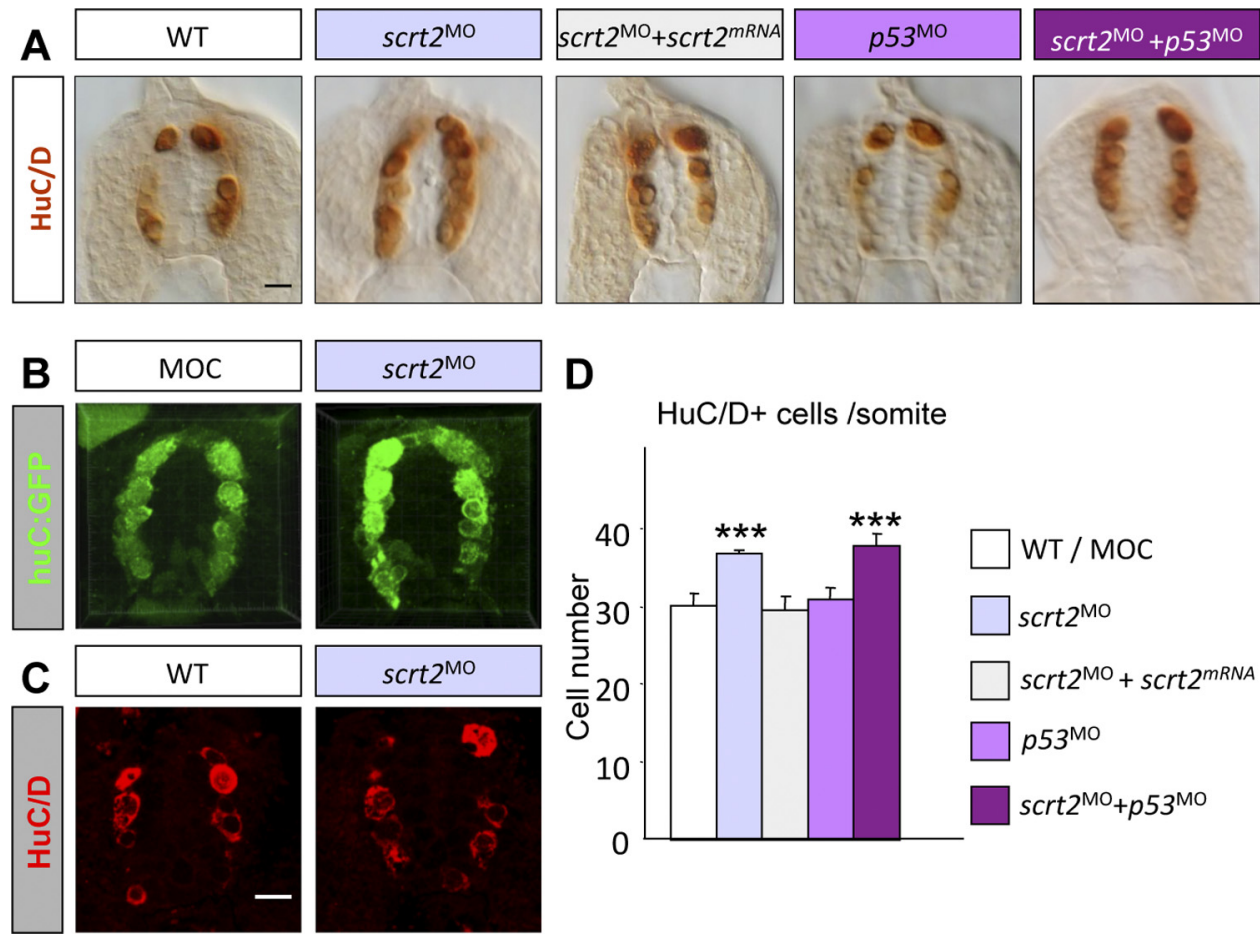

Figure 2. scratch2 knockdown induces neuronal hyperplasia in $24 \mathrm{hpf}$ zebrafish embryos. Images show transverse sections of $24 \mathrm{hpf}$ embryos at the spinal cord level. $A$, Increase in the number of postmitotic neurons in scratch 2 morphants is evident through the expression of HuC/D, a phenotype that was rescued by coinjection with scratch2 mRNA, indicating that the neuronal hyperplasia is specific to scratch 2 knockdown. The increase in postmitotic neurons in the morphants was independent of neuronal death induced by scratch 2 knockdown since blocking cell death by $p 53^{\mathrm{MO}}$ coinjection failed to rescue the neuronal hyperplasic phenotype. As expected, $p 53$ morphant embryos were indistinguishable from WT embryos. $\boldsymbol{B}$, Orthogonal projections of seven optical confocal planes reconstructed with IMARIS software. scratch2 morphants display neuronal hyperplasia. C, Confocal planes of $24 \mathrm{hpf}$ spinal cord transverse section labeled with antiHuC/D antibody. scratch2 morphants display an increase in the number of postmitotic neurons. D, Quantification of HuC/D-positive cells in embryos such as those shown in $C$ was performed under a confocal microscope through z-scans in five consecutive somites per embryo in six embryos per condition. The number of HuC/D-positive cells in each case was as follows: WT $=29.9 \pm 1.75 ;$ scratch $2^{\mathrm{MO}}=38.5 \pm 2.07$ $(p=0.00012) ;$ scratch $^{\mathrm{MO}}+$ scratch $2=29.7 \pm 1.7 ; p 53^{\mathrm{MO}}=30.7 \pm 1.7 ;$ scratch2 $^{\mathrm{MO}}+p 53^{\mathrm{MO}}=38.76 \pm 1.95\left(p=7.1 \times 10^{-5}\right)$. Scale bars: $10 \mu \mathrm{m}$.

and $n=8$ in scratcht 2 morphants). As we observed a differential response to scratch 2 knockdown in the different populations, we wondered whether this might reflect the different timing of differentiation for the three subpopulations, and also whether it was coupled with the temporal and spatial expression of scratch2. Indeed, scratch 2 expression followed a progressive dorsoventral gradient in the developing spinal cord. At the 10 somites (14 hpf) scratch 2 expression is restricted to the dorsal part of the spinal cord (Fig. $3 E$ ). At the 16 somites (17 hpf) stage expression is extended ventrally but still missing from the ventralmost region in the spinal cord (Fig. $3 F$ ). By $24 \mathrm{hpf}$, transcripts are additionally detected in MNs as reflected by their coexpression with $n k x 6.1$ (Cheesman et al., 2004) (Fig. 3G). Therefore, scratch2 knockdown may have differential effects on each subpopulation at different times that follow the postmitotic state. In agreement with this, we observed that at the 16 somite stage, the number of INs was increased in a similar manner to that observed in MNs in older embryos ( pax2a-positive cells $2.96 \pm 0.29$ in WT and $3.8 \pm$ 0.65 in scratch 2 morphants; $p=0.041$, data not shown). However, the number of MNs was not altered (1.84 \pm 0.36 in WT; $1.8 \pm 0.24$ in scratch $2^{\mathrm{MO}}$, data not shown), as expected from the absence of endogenous scratch 2 expression at this stage (Fig. $3 F$ ). Together, our data demonstrate that scratch 2 is involved in the regulation of neuronal number acting on postmitotic cells.

\section{The scratch 2 knockdown generates cycling cells in the marginal zone}

Our previous results indicated that Scratch2, expressed in postmitotic neurons, regulates the number of primary neurons, sug- gesting that it influences the cell cycle. Hence, we assessed the number and position of the mitotic cells in the spinal cord of embryos at $24 \mathrm{hpf}$, which, as described, were confined to the VZ in control embryos (Fig. $4 A$; MOC, star). In contrast, a significant number of ectopically situated mitotic cells (double labeled for $\mathrm{pH} 3$ and $\mathrm{HuC} / \mathrm{D}$ ) were evident in scratch 2 morphants (Fig. 4A, $B$; $s c r t 2^{\mathrm{MO}}$, arrowhead; $88 \%$ 22/25). This phenotype was reversed by coinjection of scratch $2 \mathrm{mRNA}$, demonstrating that this effect was specific to scratch 2 knockdown (Fig. $4 A, B$ ).

As the scratch $2^{\mathrm{MO}}$ does not induce its own mRNA degradation, we can still detect scratch 2 mRNA in the morphants, allowing us to identify the cells in which its function was downregulated. The cells containing scratch 2 mRNA were those dividing ectopically in the scratch 2 morphants (Fig. $4 C$ ), suggestive of a cellautonomous phenotype. To further analyze this phenotype, we used the $T g(h u C: G F P)$ transgenic line and labeled all nuclei with Hoechst staining. Most of these ectopically located mitotic cells in morphants were huC positive (Fig. 4D). Similar results were obtained after giving a short bromodeoxyuridine pulse to living $T g(h u C: G F P)$ embryos (data not shown). This indicates that postmitotic cells had re-entered the cell cycle. To confirm it in vivo, we generated a H2B-RFP zebrafish transgenic line (see Materials and Methods) to label all nuclei in red and cross the fish with the $T g(h u C: G F P)$ line that labels all postmitotic neurons in green. Time-lapse experiments on $24 \mathrm{hpf}$ scrt2 morphant embryos revealed that some huC:GFP-positive cells in the mantle layer entered mitosis and gave rise to two huC:GFP-labeled daughter cells (Fig. 4E). In control embryos, all mitotic figures were observed in the VZ. These results indicate that Scratch2 


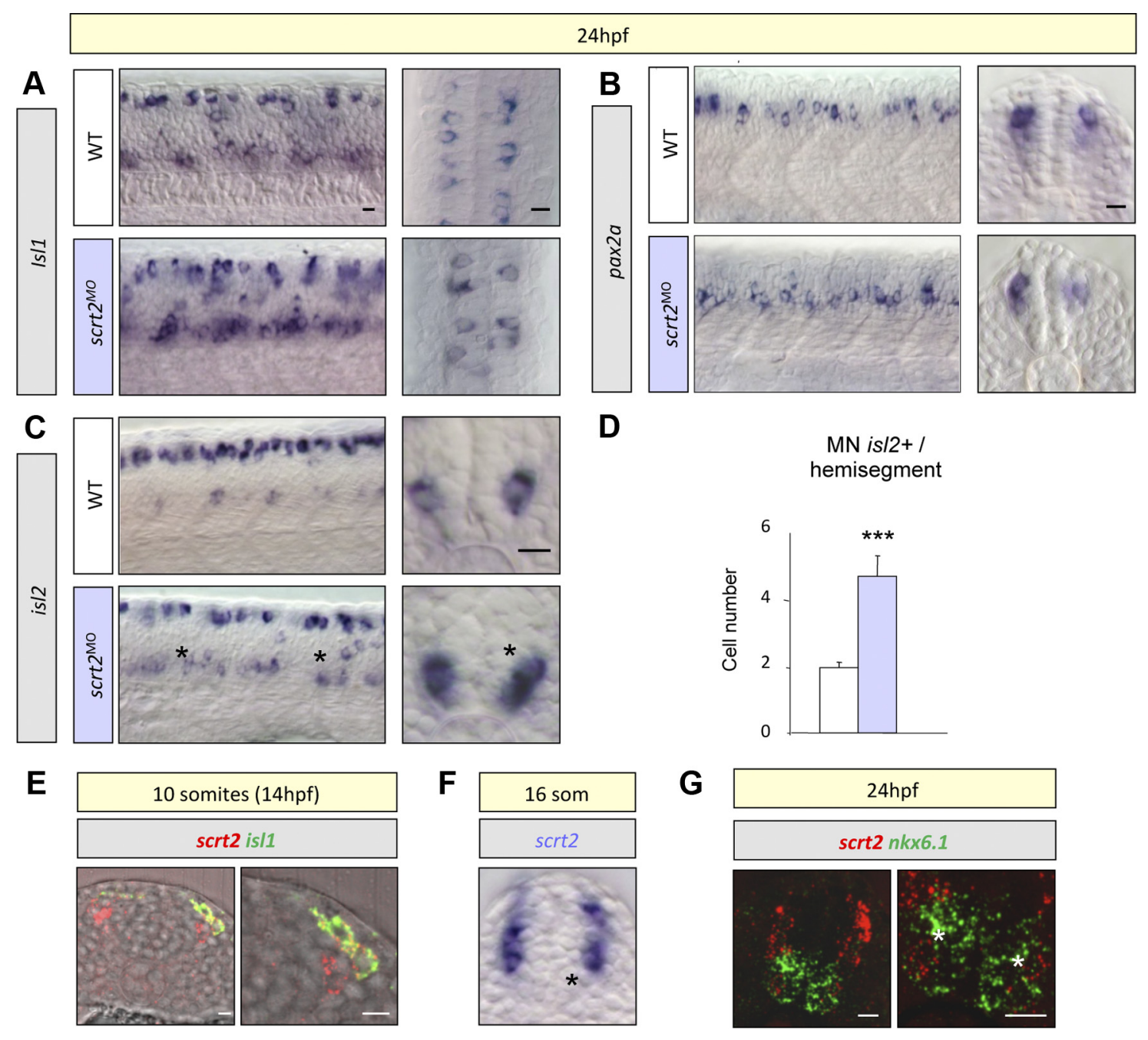

Figure 3. Scratch2 regulates the number of spinal primary neurons. Lateral flat-mounted $24 \mathrm{hpf}$ embryos shown anterior to the left. $A$, At $24 \mathrm{hpf}$, the number of RB-sensitive neurons determined by is/1 expression in the dorsal spinal cord is similar in WT and scratch2 morphants. $\boldsymbol{B}$. The number of commissural INs (pax2a-positive cells) is not altered in scratch2 morphants. $\boldsymbol{C}$, scratch2 knockdown increases the number of MNs determined by is/2-positive cells (asterisk). $\boldsymbol{D}$, Quantification of MNs from the experiment shown in $\boldsymbol{C}$. The number of is/2-positive cells was $1.94 \pm 0.18$ in WT and $4.67 \pm 0.6$ in scratch $2^{\mathrm{MO}}\left(p=1 \times 10^{-6}\right) n=6$ embryos in control embryos and $n=8$ in scratcht2 morphants. $E-G$ scratch2 expression follows a temporal dorsoventral gradient in the developing spinal cord. $\boldsymbol{E}$, At the 10 somite stage, it is expressed in the dorsal spinal cord overlapping with RB markers. $\boldsymbol{F}$, scratch2 expression in 16 somite stage embryos is absent from the ventral spinal cord (asterisk). G, By 24 hpf, scratch2 (red), is additionally coexpressed with MN markers such as nkx6.1 (green, asterisk). Scale bars: $10 \mu \mathrm{m}$.

function is required in postmitotic neurons to keep them in the postmitotic state.

\section{The expression of the p57 cell cycle inhibitor is enhanced by Scratch 2}

Our previous data indicated that Scratch 2 could act by preventing cell cycle re-entry, suggesting that it may control components of the cell cycle machinery in postmitotic neurons. Indeed, ectopic cycling neurons positive for postmitotic differentiation markers have been observed in mouse mutants for cell cycle regulators, including the p57 cell cycle inhibitor and retinoblastoma (Chen et al., 2007; Gui et al., 2007). The phenotype observed at $24 \mathrm{hpf}$ in scratch 2 morphants, with ectopic cycling neurons and an increase in $\mathrm{MN}$ number, is very similar to the that described after downregulation of the cyclin-dependent inhibitor p57 in zebrafish 20 hpf embryos (cdkn1c gene; Park et al., 2005). Moreover, we had previously reported that the closely related Snaill factor attenuates proliferation of epithelial cells by increasing the expression of the cell cycle inhibitor p21, another CKI family member (Vega et al., 2004; de Frutos et al., 2007). Considering the phenotypic similarities and the fact that $\mathrm{p} 57$ is the only CKI described in the embryonic zebrafish spinal cord (Park et al., 2005), we studied the relationship between Scratch2 and p57. We observed that the level of $c d k n 1 c$ transcripts diminished in $24 \mathrm{hpf}$ embryos injected with scratch $2^{\mathrm{MO}}$ (Fig. 5A). Furthermore, p57 overexpression by injection of $c d k n 1 c$ mRNA was able to rescue the phenotype of scratch 2 morphants (Fig. 5B) as indicated by the reduction of ectopic pH3-positive cells (Fig. 5C). Altogether, these data indicate that the phenotype observed in scratch 2 morphants is associated with aberrant low levels of p57, suggesting that Scratch2 may increase p57 expression in vivo.

\section{Scratch2 increases $c d k n 1 c$ transcripts by downregulating miR-25 expression}

With a few exceptions, Scratch and Snail factors act as transcriptional repressors (Nakakura et al., 2001), suggesting that the induction of $c d k n 1 c$ expression by Scratch2 might occur indirectly, perhaps through the repression of a p57 repressor. As microRNAs (miRs) play an important role as cell cycle regulators by modulating the levels of CKIs (Bueno et al., 2008; Kim et al., 
A
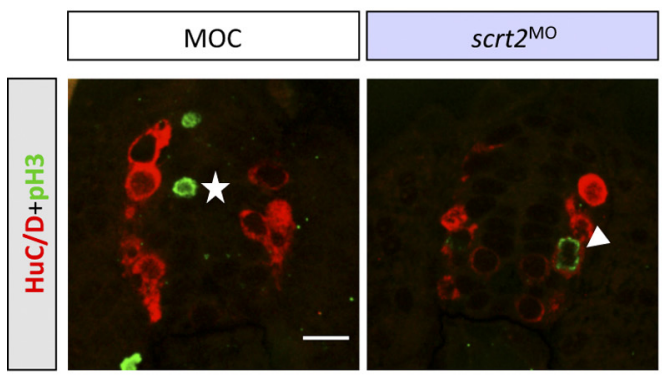

C
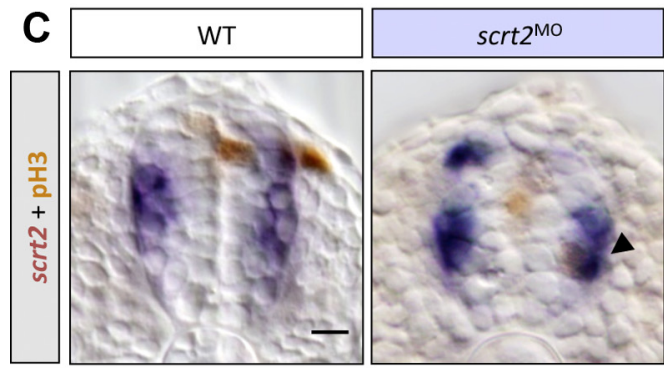

$\mathbf{E}$
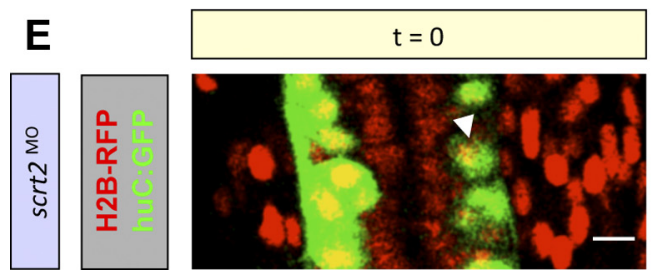
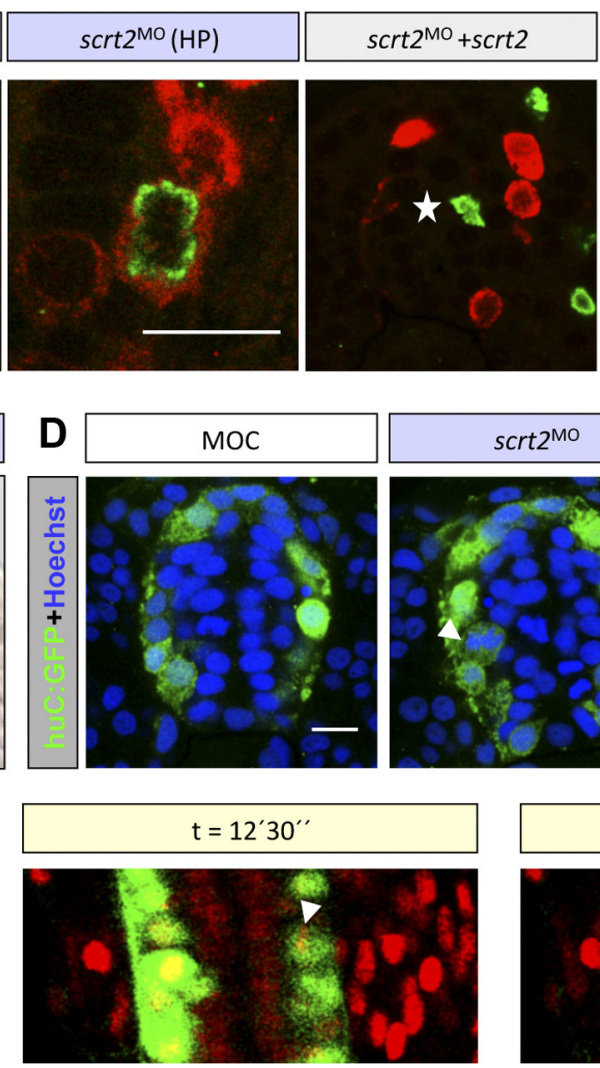

B

$\mathrm{pH} 3+$ cells

out of $\mathrm{VZ} /$ somite

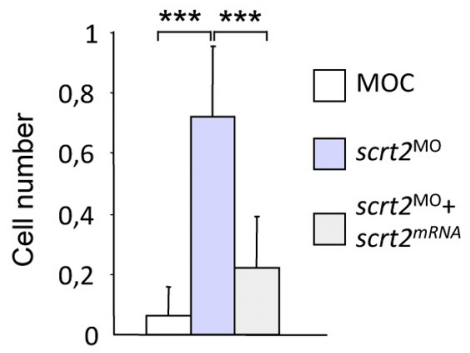

Figure 4. Scratch2 prevents neuronal cell cycle re-entry. A, Transverse confocal images of $24 \mathrm{hpf}$ zebrafish embryos showing mitotic cells (pH3 immunostaining, green) and HuC/D-positive neurons (red). In control embryos pH3-positive cells were located in the VZ (star), while in the scratch2 morphants (scratch2 ${ }^{\mathrm{MO}}$ ) additional pH3-positive cells evident in the mantle layer were also positive for HuC/D (arrowhead). These ectopic mitotic cells were specifically generated by scratch2 downregulation as coinjection of scratch2 $\mathrm{mRNA}$ rescued the phenotype (star). $\boldsymbol{B}$, The number of ectopic mitotic cells was quantified in the different conditions, confirming the specificity of the scratch 2 phenotype. Ten embryos were quantified per condition. Quantifications: WT $=0.06 \pm 0.097 ;$ scratch $^{\mathrm{MO}}=0.72 \pm 0.23\left(p=2.89 \times 10^{-6}\right)$; scratch $^{\mathrm{MO}}+$ scratch $^{\mathrm{mRNA}}=0.22 \pm 0.17\left(p=5.16 \times 10^{-5}\right.$ vs scratch $\left.2^{\mathrm{MO}}\right)$. C, The presence of ectopic mitotic cells in the mantle layer was confirmed by the existence of scratch2/pH3-positive cells in the morphants (arrowhead). D, $\operatorname{Tg}($ huC:GFP) embryos with nuclei stained for Hoechst (blue) confirm the presence of mitotic figures in huC-positive cells in scratch2 morphants (arrowhead), indicating that these embryos have defects in cell cycle regulation. HP, High-power magnification. E, Time-lapse analysis of living $\mathrm{Tg}($ huC:GFP/XEF7a:H2B-RFP) double transgenic embryos showing cell divisions in huC-positive neurons in scratch2 morphants, anterior up. Snapshots taken from the same confocal plane at different time points show huC-positive cells (green) with red nuclei. White arrowhead points to a green cell, where the nucleus undergoes mitosis, later giving rise to two huC:GFP-positive daughter cells. Scale bars: $10 \mu \mathrm{m}$.

2009) we wondered whether Scratch2 could indirectly increase $c d k n 1 c$ expression by repressing a miR. To address this possibility, we searched for $\mathrm{miR}$ target sites in the $c d k n 1 c 3^{\prime} \mathrm{UTR}$ region. Of those found, we focused on miR-25 since it can reduce $c d k n 1 c$ mRNA levels in human cancer cells (Kim et al., 2009). miR-25 is highly conserved among vertebrates, and it belongs to the miR-106b 25 cluster located in an intron of the $m \mathrm{~cm} 7$ gene (Tanzer and Stadler, 2004; Aagaard et al., 2008).

We first investigated whether miR-25 might regulate $c d k n 1 c$ expression by analyzing the activity of the zebrafish $c d k n 1 c$ 3'UTR sequence containing the miR-25 binding site in a luciferase reporter vector. After injecting this construct into embryos together with the $m i R-106 b \sim 25$ cluster, luciferase activity was repressed at $24 \mathrm{hpf}$, indicating that $c d k n 1 c$ is a target of miR-25 in vivo (Fig. 6A). To confirm
A

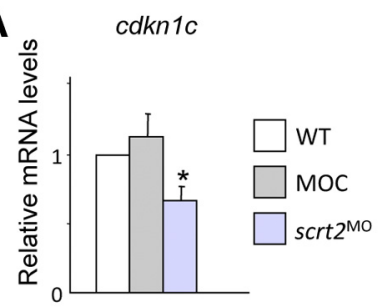

B $\mathrm{pH} 3+$ cells
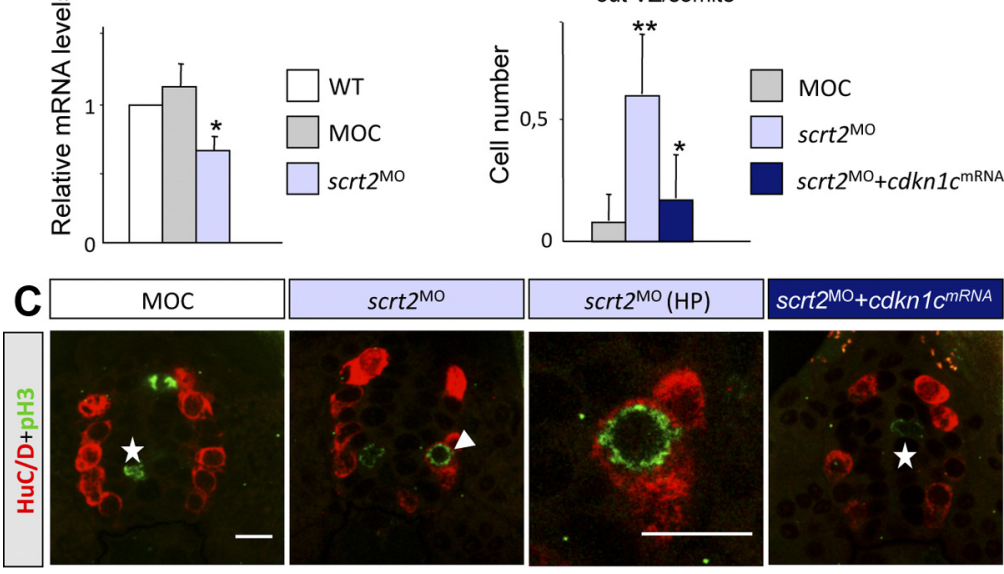

$s c r t 2^{\mathrm{MO}}+c d k n 1 c^{\mathrm{mRNA}}$

Figure 5. Scratch2 increases c $d k n 1 c$ expression. $A$, scratch 2 morphants have reduced levels of $c d k n 1 c$ transcripts as assessed by qPCR in 24 hpf embryos. Expression of $c d k n 1 c$ in MOC: $1.12 \pm 0.17$; scrt2 ${ }^{\mathrm{MO}}: 0.67 \pm 0.10, p=0.032$ related to WT $=1 . n=3$ experiments. $\boldsymbol{B}$, The aberrant presence of pH3-positive cells outside the VZ in the morphants is rescued by cdkn1 coverexpression. C, Cells double labeled for pH3 (green) and HuC/D (red) reflect the presence of differentiated neurons undergoing mitosis (arrowhead) unlike control and rescue conditions (star). This phenotype is rescued in embryos coinjected with scratch ${ }^{\mathrm{MO}}$ and $c d k n 1 c^{\mathrm{mRNA}}$. Quantification:

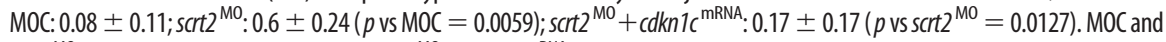
scrt2 ${ }^{\mathrm{MO}}$ embryos, $n=5$ per condition and scrt2 ${ }^{\mathrm{M} 0}+c^{2} \mathrm{kn} n c^{\mathrm{mRNA}}$ embryos, $n=7$. Scale bars: $10 \mu \mathrm{m}$. 
A

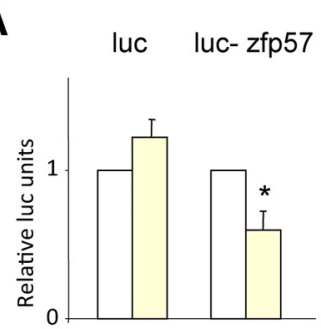

\section{B}
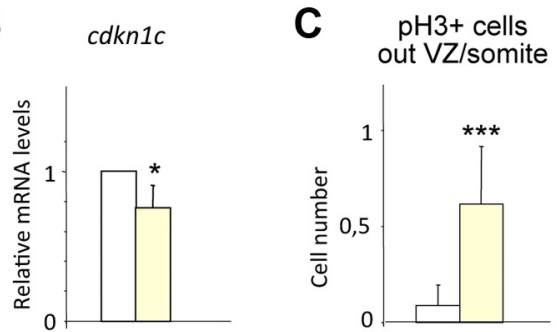

\section{D}

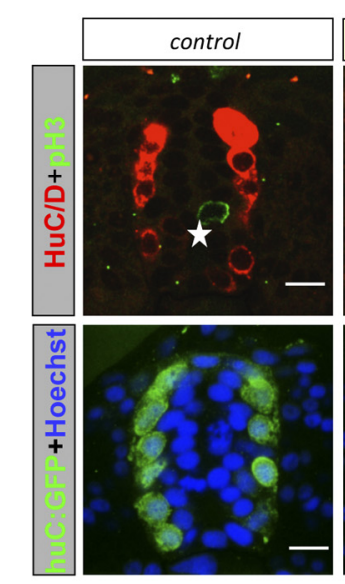

control $\square$ hsa-miR-25
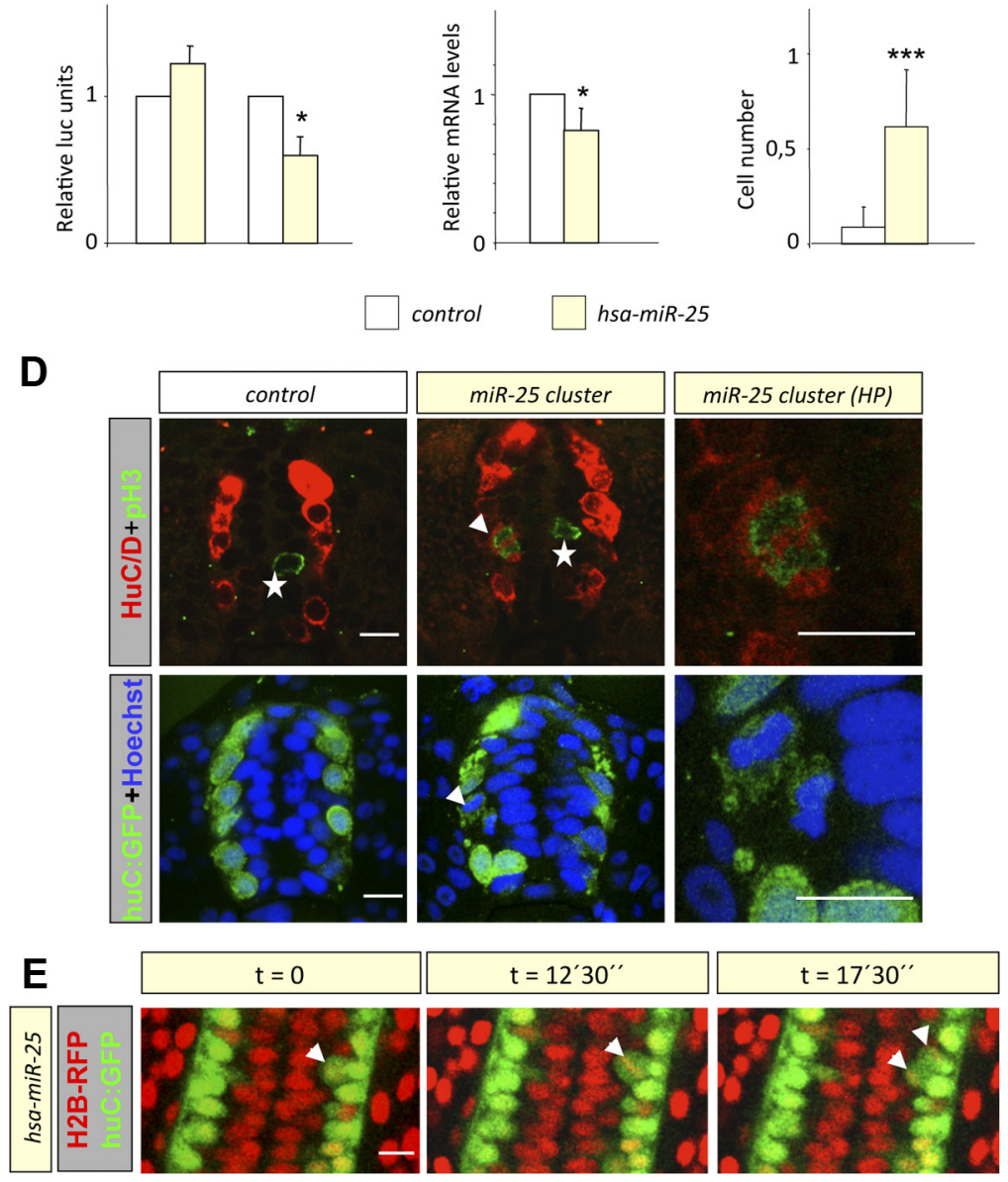

Figure 6. miR-25 overexpression induces HuC/D positive cells to re-enter mitosis. A, miR-25 represses a zebrafish 3'UTR cdkn1C luciferase (luc) reporter in vivo, indicating that $c d k n 1 c$ is a miR-25 target gene in zebrafish. The results shown are the mean of three independent experiments, and measured relative to the control condition (value $=1$ ). miR-25 overexpression represses the activity of p57 $3^{\prime}$ UTR by $40 \%(0.59 \pm 0.13 ; p=0.03)$. $B$, miR-25 overexpression is accompanied by a decrease in the levels of cdkn1c transcripts. hsa-miR-25 $=0.74 \pm 0.21$ related to $M O C=1, p=0.17 ; n=3$ experiments. $\boldsymbol{C}, \boldsymbol{D}$, The decrease in cdkn1c expression observed after miR-25 overexpression was accompanied by the appearance of mitotic cells outside the VZ in $24 \mathrm{hpf}$ embryos. As in scratch2 morphants, these cells are positive for both pH3 (green) and HuC/D (red) (arrowhead) in contrast to control embryos (star). Note the appearance of irregular nuclei stained with Hoechst in $\boldsymbol{D}$ (arrowhead).The number of pH3-positive cells outside the VZ per somite increased in miR-25 overexpressing embryos ( $0.61 \pm 0.3$ vs $0.086 \pm 0.11$ in control embryos, $p=$ $5.67 \times 10^{-5}$ ). Quantification was performed on five control and 10 miR-25 overexpressing embryos. $\boldsymbol{E}$, Time-lapse analysis of living Tg (huC:GFP/XEFTa:H2B-RFP) double transgenic embryos. Some huC-positive cells (green) enter mitosis and give rise to two daughter cells (arrowhead). Images taken at a single focal plane at different time points. Scale bars: $10 \mu \mathrm{m}$.

that the targeting of $c d k n 1 c$ mRNA by miR-25 could have functional consequences, we analyzed the effect of miR-25 overexpression in the embryos. We found that injection of the $m i R-25$ cluster reduced the levels of $c d k n 1 c$ transcripts in embryos analyzed at $24 \mathrm{hpf}$ (Fig. 6B). The developing spinal cords contained (1) cells double positive for $\mathrm{pH} 3$ and $\mathrm{HuC} / \mathrm{D}$ located outside the VZ and (2) GFP-positive cells with nuclei showing mitotic figures when the $m i R-25$ cluster was injected into $\mathrm{Tg}(h u C: G F P)$ transgenic embryos (Fig. 6C,D). To better assess whether cells divide after they have acquired the expression of postmitotic markers, we followed the process in vivo by injecting miR-25 mRNA into $\mathrm{Tg}(\mathrm{huC}$ :GFP/xEF1a:H2B-RFP) double transgenic embryos. $m i R-25$ overexpression resulted in the appearance of huC:GFP-positive cells entering mitosis and giving rise to two daughter cells (Fig. 6E), a phenotype reminiscent of that observed in scratch 2 morphants.
The similarity between the two phenotypes suggests that miR-25 could mediate the function of Scratch2 in the control of neuronal number in the zebrafish spinal cord. To address this question, we first analyzed miR-25 expression levels in embryos injected with scratch $2^{\mathrm{MO}}$ and found that these morphants had higher levels of mature $m i R-25$ than the control embryos (Fig. 7A). This result is compatible with the decrease observed in $c d k n 1 c$ expression (Fig. 6B) and with the downregulation of $m i R-25$ expression by Scratch2. However, the levels of $m \mathrm{~cm} 7$, the host gene for miR-25, were not altered (Fig. $7 B$ ), suggesting that $m i R-25$ and $m c m 7$ may use independent promoters, as suggested previously (Sikand et al., 2009; Monteys et al., 2010; Brett et al., 2011).

Our data suggest that Scratch2 prevents postmitotic neurons from re-entering the cell cycle by inhibiting miR-25 expression, which in turn leads to p57 activation. If true, the cell cycle re-entry that we had observed in postmitotic neurons in scratch 2 morphants should be reverted upon miR-25 downregulation. To decrease $m i R-25$ in the embryos, we used $m i R-25^{\mathrm{MO}}$ injection. It is worth noting that miR-25 inhibition induces cell death, very likely because miR-25 also targets $p 53$ mRNA and that of the proapoptotic molecule bim (Petrocca et al., 2008; Kumar et al., 2011). Therefore, in these experiments we also coinjected $p 53^{\mathrm{MO}}$ to prevent cell death. This coinjection strategy, referred to as $m i R-25^{\mathrm{MO}} \mathrm{s}$ ( $\mathrm{s}$ for survival), allowed us to assess the effect of miR-25 inhibition in the embryos without the interference produced by neuronal loss (Fig. 7C). We next confirmed that $m i R-25^{\mathrm{MO}}$ was attenuating miR-25 function. We injected it into zebrafish embryos overexpressing miR-25 and observed that it could rescue the activity of the luciferase reporter vector containing the $c d k n 1 c 3^{\prime}$ UTR sequence with the miR-25 binding site (Fig. 7D). This indicates that $m i R-25^{\mathrm{MO}}$ is functional in vivo.

Injection of $m i R-25 \mathrm{MO}$ in embryos prevented the appearance of the ectopic cycling cells induced by scratch 2 downregulation (Fig. 7E,F). This effect was accompanied by the restoration of normal $c d k n 1 c$ transcript levels (Fig. $7 G$ ). Finally, the number of isl2-positive MNs was rescued in $24 \mathrm{hpf}$ embryos (Fig. $7 \mathrm{H}, \mathrm{I}$ ), demonstrating that supernumerary neurons found in scratch 2 morphants are the result of $\mathrm{HuC} / \mathrm{D}$ cells that have re-entered the cell cycle and divided giving rise to two daughter cells. Together, our results indicate that Scratch2 downregulates miR-25 expression, which in turn leads to p57 activation and prevents postmitotic neurons from re-entering the cell cycle (Fig. 8).

\section{Discussion}

Postmitotic neurons must keep their cell cycle permanently in check to prevent their reversion into a proliferative state 
A

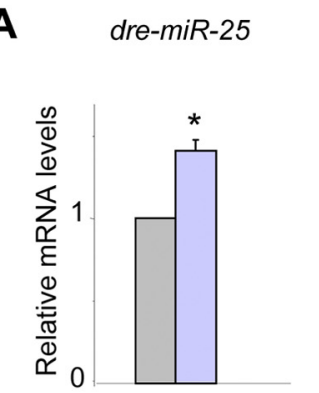

B $\quad m c m 7$

D luc- zfp57

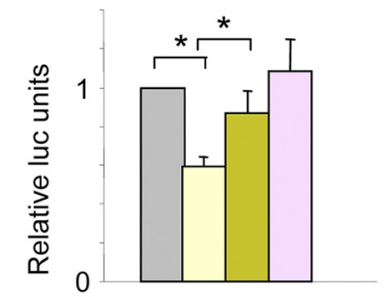

C
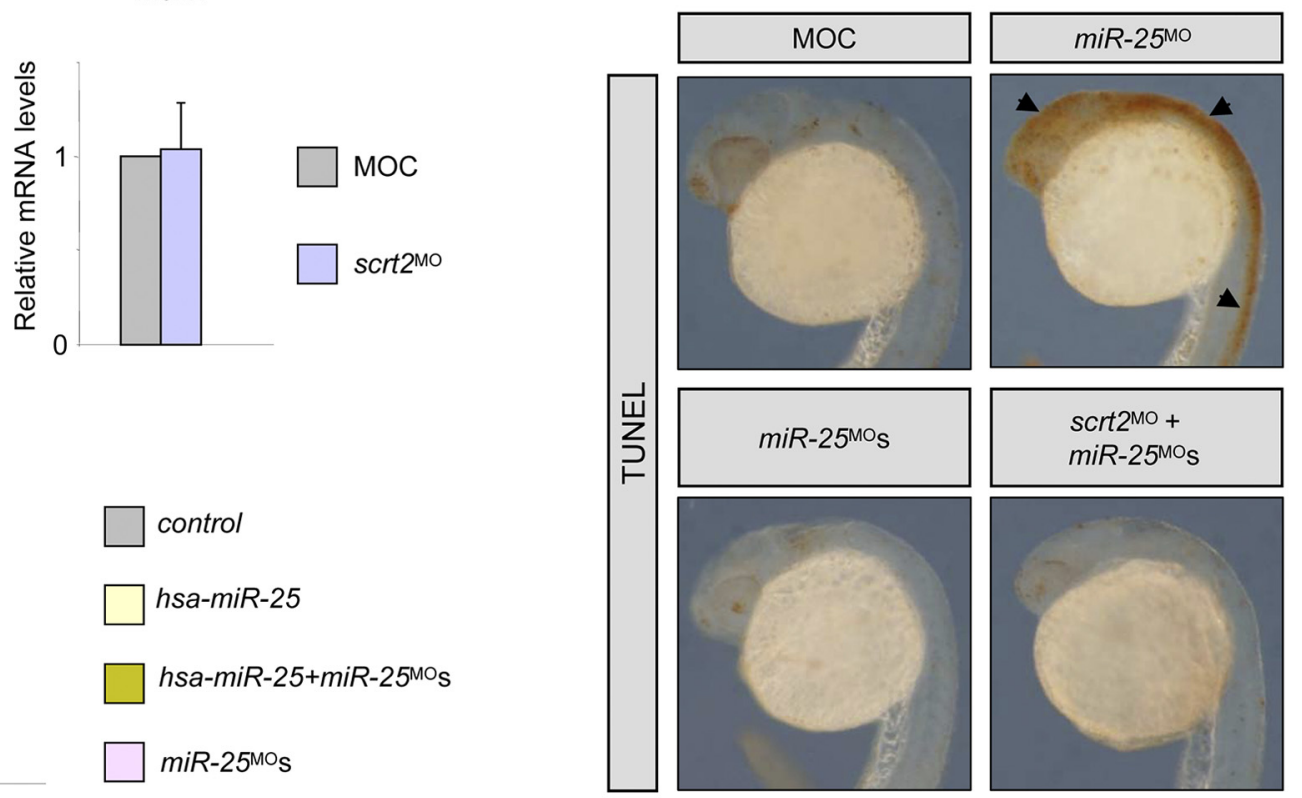

\section{E}
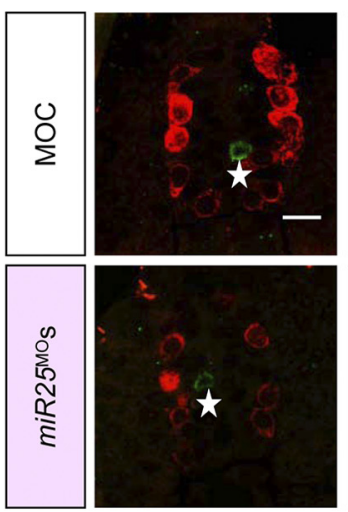

\section{$\mathrm{HuClD}+$}
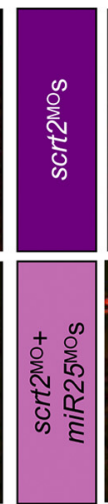
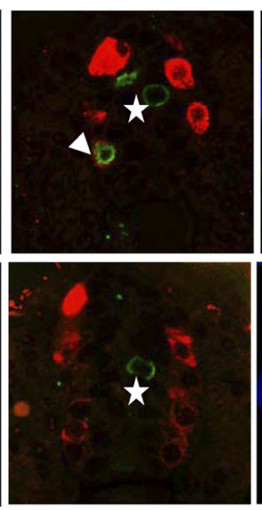

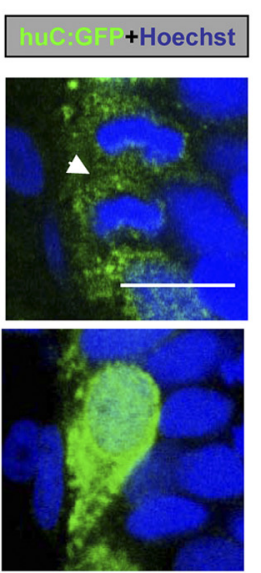

$\mathbf{F}$

$\mathrm{pH} 3+$ cells out of $\mathrm{VZ} /$ somite

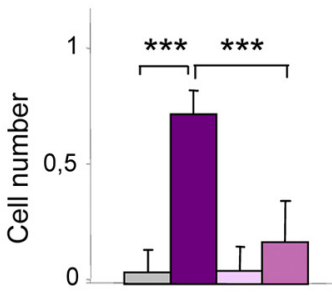

G

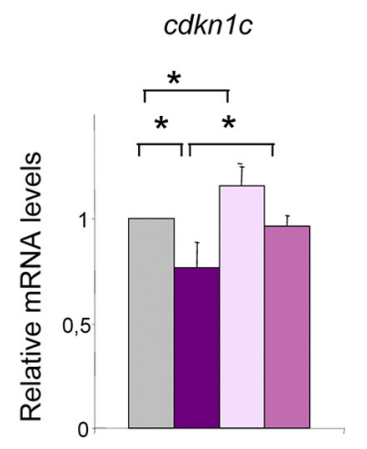

MOC

$\operatorname{scrt}^{\mathrm{MO}} \mathrm{S}$

$\mathrm{miR}-25^{\mathrm{MOS}}$ $s c r t 2 \mathrm{MO}+m i R-25 \mathrm{MO}_{\mathrm{S}}$
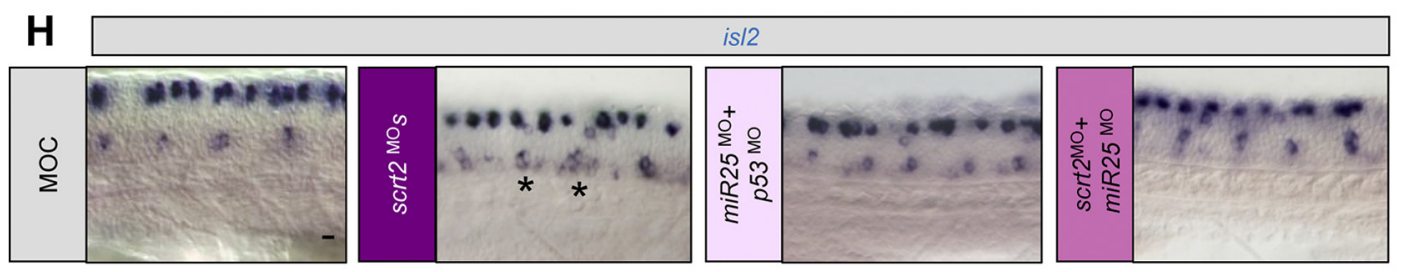

\section{I}

is/2+ cells / hemisegment

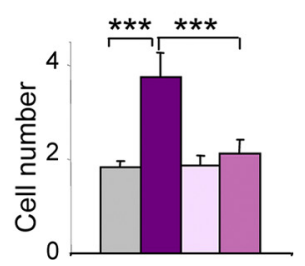

Figure 7. Scratch2 prevents cell cycle re-entry by regulating miR-25 expression. $\boldsymbol{A}, \boldsymbol{B}$, miR-25 is upregulated in scrt2 morphants but $m c m 7$, miR-25 host gene, does not appear altered. $\boldsymbol{A}$, Expression of dre-miR-25 in scrt2 ${ }^{\mathrm{MO}}=1.42 \pm 0.069$ related to $\mathrm{MOC}(1), p=0.01, n=3$ experiments. $\boldsymbol{B}$, Expression of $m c m 7$ in scrt2 ${ }^{\mathrm{MO}}=1.04 \pm 0.24$ related to $\mathrm{MOC}=1, n=$ 3 experiments. C, miR-25 ${ }^{\mathrm{MO}}$ injection induces apoptosis in $92 \%$ of the embryos examined ( $n=30$, arrowheads). This cell death can be prevented by coinjecting $p 53 \mathrm{MO}$ ( $m i R-25^{\mathrm{MO}} \mathrm{s}$, $93.5 \% ; n=46)$. Embryos coinjected with miR-25 ${ }^{\mathrm{MO}}$ s and scrt2 ${ }^{\mathrm{M} 0}$ appeared as WT $(81 \% ; n=41) . \boldsymbol{D}$, miR-25 ${ }^{\mathrm{M} 0}$ is functional. miR-25 ${ }^{\mathrm{M} 0}$ injection prevents the repression of the $\mathrm{p} 573^{\prime} \mathrm{UTR}$ reporter observed after miR- 25 overexpression. miR- 25 represses the reporter by $40 \%\left(0.59 \pm 0.04, p=0.004\right.$ ) while miR- $25+$ miR- $25^{\mathrm{M0}}=0.86 \pm 0.12$ ( $p$ vs miR-25 $\left.=0.044\right)$. The results shown are the mean of three independent experiments. $\mathbf{E}-\mathbf{G}$, miR-25${ }^{\mathrm{MO}}$ injection rescues the cell cycle phenotype observed in scratch2 morphants (star), both in terms of pH3-positive cells outside the VZ double labeled with HuC/D or in $T g(h u C: G F P)$ transgenic embryos with mitotic nuclei labeled with Hoechst $(\boldsymbol{E}, \boldsymbol{F}$, arrowhead, $n=6)$ and $c d k n 1 c$

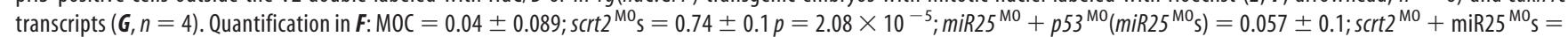

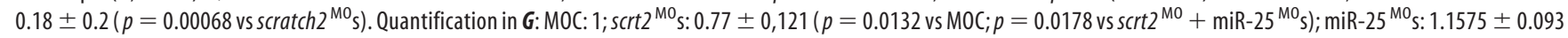
$(p=0.043 \mathrm{vs} \mathrm{MOC}) ; s c r t 2{ }^{\mathrm{MO}}+m_{i R}-25^{\mathrm{MO}} \mathrm{s}: 0.968 \pm 0.049 . \mathbf{H}, \mathbf{I}$, The increase in the number of is/2-expressing cells in scratch2 morphants (asterisks) reverted to that in WT embryos when miR-25 was downregulated. Quantification was performed in six embryos per condition. $\mathrm{MOC}=1.83 \pm 0.14 ; \mathrm{scrt}^{\mathrm{MO}} \mathrm{s}=3.75 \pm 0.51 p=0.00012 ; \mathrm{miR}^{\mathrm{MO}}+p 53^{\mathrm{MO}}=1.87 \pm$ $0.2 ; s c r t 2^{\mathrm{MO}}+\operatorname{miR25} 5^{\mathrm{M0}} \mathrm{s}=2.11 \pm 0.3 . p$ compared with scrt2 ${ }^{\mathrm{MO}} \mathrm{s}=0.00010$. Scale bars: $10 \mu \mathrm{m}$. 


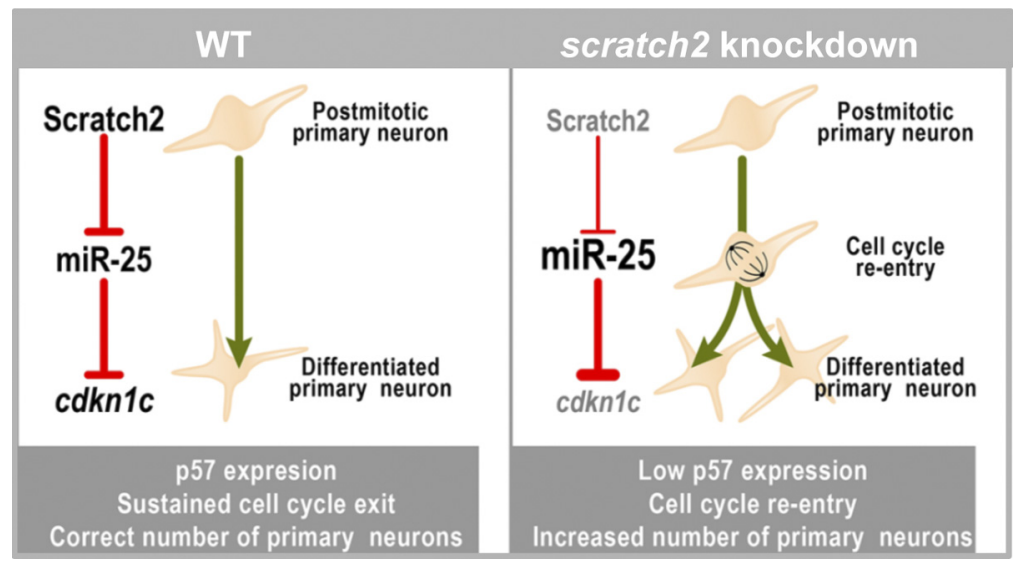

Figure 8. Scratch2 in primary neuron differentiation. Scratch2 is included in the neuronal differentiation program acting in postmitotic neurons. It prevents cell cycle re-entry by indirectly maintaining high levels of the cell cycle inhibitor p 57 through the downregulation of miR-25 expression. When scratch 2 is knocked down, increased miR-25 levels in postmitotic neurons repress cdkn1c transcript levels allowing cell cycle re-entry and leading to an increase in the number of primary neurons.

expression. Therefore, it appears that different cell types can respond differently depending on factors such as specific cell death pathways, neuronal metabolism, epigenetic processes, or even morphology, which can make some cells more prone to be reprogrammed than others (reviewed by Buttitta and Edgar, 2007 and Davis and Dyer, 2010). In addition to, cyclinD expression decreases in mature cells as differentiation proceeds (Skapek et al., 2001; Laine et al., 2010), which can make more mature cells lacking cell cycle components be more prone to undergo cell death than cell cycle re-entry.

An important question raised by our initial results was whether Scratch2 regulated the cell cycle independently of its role in the apoptotic pathway. We previously found that aberrant apoptosis in scratch 2 morphants induces compensa-

(Herrup and Yang, 2007). Indeed, cell cycle re-entry is associated with neuronal vulnerability (Herrup and Yang, 2007). Here, we show that Scratch2 regulates the cell cycle of spinal postmitotic neurons in the developing zebrafish embryo. Scratch2 maintains the levels of the CKI family member p57, thereby preventing them from re-initiating proliferation and ensuring neuronal homeostasis.

The increase in the number of neurons that we observed in scratch 2 morphants is reminiscent of that observed in mutants for cell cycle components in the mouse (Chen et al., 2007; Gui et al., 2007) and in particular to that described in the spinal cord of zebrafish $c d k n 1 c$ morphants, where p57 is the only known CKI expressed (Park et al., 2005). CKIs and p57 in particular, are expressed in progenitors to arrest proliferation. Newborn p57 mutant mice die soon after birth and display defects related to tissue growth, delayed differentiation, and increased apoptosis in several organs that could be interpreted as the result of progenitors undergoing additional rounds of division before differentiation (Yan et al., 1997; Zhang et al., 1997; Georgia et al., 2006). Here, we demonstrate that scratch 2 downregulation decreases the levels of $c d k n 1 c$ transcripts after neurons have exited the cell cycle, as Scratch2 is expressed in postmitotic neurons. Therefore, the phenotype observed after scratch 2 knockdown is caused by postmitotic cells re-entering the cell cycle while they continue to express neuronal differentiation markers. Thus, independently of the role of p57 in promoting cell cycle withdrawal in committed progenitors, Scratch2 specifically acts in postmitotic neurons, maintaining p57 expression high after cell cycle exit, preventing reversion to the proliferative state.

Inappropriate cell cycle re-entry has been associated with cell death and indeed observed in a wide variety of animal models and pathological states such as neurodegenerative disorders (Lee et al., 1992; Dyer and Cepko, 2000; Zhang et al., 2008; reviewed by Herrup and Yang, 2007). These studies have shown that the abnormal DNA replication that occurs when neurons can re-enter the S-phase is rapidly followed by cell death. However, cell cycle re-entry does not seem to lead to neuronal death in scratch 2 morphants or in embryos overexpressing miR-25, as we observe neurons able to progress into late $\mathrm{G} 2-\mathrm{M}$ phase ( $\mathrm{pH} 3$ positive). Furthermore, live imaging analysis shows that aberrantly dividing postmitotic neurons complete mitosis and give rise to two daughter cells both after scratch 2 knockdown and miR-25 over- tory proliferation of the progenitors in an attempt to replenish the damaged tissue (Rodríguez-Aznar and Nieto, 2011). By preventing cell death by downregulation of the p53 pathway, we demonstrate here that the two pathways can act independently albeit simultaneously, confirming that coordinating the survival and the proliferation block mediated by Scratch 2 contributes to the final number of neurons.

Our data also indicate that the influence of Scracth2 on the neuronal differentiation program is not associated with a particular fate, as scratch2 downregulation affects the number of both INs and MNs. By analyzing the phenotype of scratch 2 morphants at different developmental stages, we have revealed that Scratch 2 acts along the dorsoventral gradient of differentiation, evident through its sequential onset of expression in INs and MNs in a cell-autonomous manner.

A key finding of the present study is that Scratch 2 controls p57 expression through the downregulation of miR-25, through which Scratch 2 prevents neuronal cell cycle re-entry. These results expand the importance of miRs in embryonic development, ranging from the definition of embryonic territories (Spruce et al., 2010) to neuronal differentiation and homeostasis. Interestingly, miR-9 was recently shown to regulate cell cycle exit and apoptosis in the Xenopus nervous system by downregulating the expression of the hairy1 transcription factor in neuronal progenitors (Bonev et al., 2011). They show that miR-9 is required in the progenitors for cell cycle exit, and we show here that miR-25 subsequently acts in postmitotic neurons to prevent them from re-initiating proliferation. Thus, in addition to the sequential specification of neural fates by transcription factor codes (Guillemot, 2007), it appears that a superimposed sequential use of different miRs, including miR-25 and miR-9, adds a new level of regulation to the neural differentiation program.

Our observations in the developing zebrafish spinal cord are likely to be relevant to other systems, not least because miR-25 is highly conserved in vertebrates and p57 has been implicated in regulating the cell cycle of neural precursors in the mouse cerebral cortex (Tury et al., 2011). The novel role described here for Scratch 2 and p57 in preventing cell cycle re-entry in postmitotic neurons may provide new insight into cell cycle control, not only during embryonic development but also in adult neurons and following its deregulation in pathological conditions. Interestingly, Scratch2 is expressed in distinct regions of the adult mouse 
brain (Marín and Nieto, 2006) and our preliminary experiments in zebrafish indicate that it is present in wider areas, compatible with the fact that extensive neurogenesis has been described in the adult zebrafish brain (Zupanc et al., 2005). For example, cell cycle components are deregulated in Alzheimer's or Parkinson's diseases (Höglinger et al., 2007; Varvel et al., 2009) and the miR106b 25 cluster is upregulated in human gastric cancer (Petrocca et al., 2008). Interestingly, miR-106b and miR-93, the other members of the miR106b 25 cluster, target p21 (Bueno et al., 2008; Kim et al., 2009) and we previously reported that Snail1, an important element in tumor progression closely related to Scratch (Nieto, 2011), attenuates proliferation by increasing p 21 expression in different cell contexts (Vega et al., 2004; de Frutos et al., 2007).

Together, the present findings demonstrate that Scratch2, in addition to protecting neurons from cell death by directly maintaining low levels of Puma (Rodríguez-Aznar and Nieto, 2011), prevents neuronal re-entry into the cell cycle by indirectly maintaining the levels of the cell cycle inhibitor p57 high. Thus, Scratch2 appears to safeguard the homeostasis of primary neurons acting through two independent albeit simultaneous mechanisms.

\section{References}

Aagaard LA, Zhang J, von Eije KJ, Li H, Saetrom P, Amarzguioui M, Rossi JJ (2008) Engineering and optimization of the miR-106b cluster for ectopic expression of multiplexed anti-HIV RNAs. Gene Ther 15:1536-1549. CrossRef Medline

Acloque H, Wilkinson DG, Nieto MA (2008) In situ hybridization analysis of chick embryos in whole-mount and tissue sections. Methods Cell Biol 87:169-185. CrossRef Medline

Ajioka I, Martins RA, Bayazitov IT, Donovan S, Johnson DA, Frase S, Cicero SA, Boyd K, Zakharenko SS, Dyer MA (2007) Differentiated horizontal interneurons clonally expand to form metastatic retinoblastoma in mice. Cell 131:378-390. CrossRef Medline

Alcaraz-Pérez F, Mulero V, Cayuela ML (2008) Application of the dualluciferase reporter assay to the analysis of promoter activity in Zebrafish embryos. BMC Biotechnol 8:81. CrossRef Medline

Appel B, Korzh V, Glasgow E, Thor S, Edlund T, Dawid IB, Eisen JS (1995) Motoneuron fate specification revealed by patterned LIM homeobox gene expression in embryonic zebrafish. Development 121:4117-4125. Medline

Balciunas D, Wangensteen KJ, Wilber A, Bell J, Geurts A, Sivasubbu S, Wang X, Hackett PB, Largaespada DA, McIvor RS, Ekker SC (2006) Harnessing a high cargo-capacity transposon for genetic applications in vertebrates. PLoS Genet 2:e169. CrossRef Medline

Bally-Cuif L, Hammerschmidt M (2003) Induction and patterning of neuronal development, and its connection to cell cycle control. Curr Opin Neurobiol 13:16-25. CrossRef Medline

Bonev B, Pisco A, Papalopulu N (2011) MicroRNA-9 reveals regional diversity of neural progenitors along the anterior-posterior axis. Dev Cell 20: 19-32. CrossRef Medline

Brett JO, Renault VM, Rafalski VA, Webb AE, Brunet A (2011) The microRNA cluster miR-106b 25 regulates adult neural stem/progenitor cell proliferation and neuronal differentiation. Aging 3:108-124. Medline

Bueno MJ, Pérez de Castro I, Malumbres M (2008) Control of cell proliferation pathways by microRNAs. Cell Cycle 7:3143-3148. CrossRef Medline

Buttitta LA, Edgar BA (2007) Mechanisms controlling cell cycle exit upon terminal differentiation. Curr Opin Cell Biol 19:697-704. CrossRef Medline

Cheesman SE, Layden MJ, Von Ohlen T, Doe CQ, Eisen JS (2004) Zebrafish and fly Nkx6 proteins have similar CNS expression patterns and regulate motoneuron formation. Development 131:5221-5232. CrossRef Medline

Chen D, Opavsky R, Pacal M, Tanimoto N, Wenzel P, Seeliger MW, Leone G, Bremner R (2007) Rb-mediated neuronal differentiation through cellcycle-independent regulation of E2f3a. PLoS Biol 5:e179. CrossRef Medline

Davis DM, Dyer MA (2010) Retinal progenitor cells, differentiation, and barriers to cell cycle reentry. Curr Top Dev Biol 93:175-188. CrossRef Medline

de Frutos CA, Vega S, Manzanares M, Flores JM, Huertas H, Martínez-Frías ML, Nieto MA (2007) Snaill is a transcriptional effector of FGFR3 signaling during chondrogenesis and achondroplasias. Dev Cell 13:872-883. CrossRef Medline

Devès M, Bourrat F (2012) Transcriptional mechanisms of developmental cell cycle arrest: problems and models. Semin Cell Dev Biol 23:290-297. CrossRef Medline

Dyer MA, Cepko CL (2000) p57 $7^{\text {kip2 }}$ regulates progenitor cell proliferation and amacrine interneuron development in the mouse retina. Development 127:3593-3605. Medline

Georgia S, Soliz R, Li M, Zhang P, Bhushan A (2006) p57 and Hes1 coordinate cell cycle exit with self-renewal of pancreatic progenitors. Dev Biol 298:22-31. CrossRef Medline

Gui H, Li S, Matise MP (2007) A cell-autonomous requirement for Cip/Kip cyclin-kinase inhibitors in regulating neuronal cell cycle exit but not differentiation in the developing spinal cord. Dev Biol 301:14-26. CrossRef Medline

Guillemot F (2007) Spatial and temporal specification of neural fates by transcription factor codes. Development 134:3771-3780. CrossRef Medline

Herrup K, Yang Y (2007) Cell cycle regulation in the postmitotic neuron: oxymoron or new biology? Nat Rev Neurosci 8:368-378. CrossRef Medline

Höglinger GU, Breunig JJ, Depboylu C, Rouaux C, Michel PP, AlvarezFischer D, Boutillier AL, Degregori J, Oertel WH, Rakic P, Hirsch EC, Hunot S (2007) The pRb/E2F cell-cycle pathway mediates cell death in Parkinson's disease. Proc Natl Acad Sci U S A 104:3585-3590. CrossRef Medline

Hutchinson SA, Eisen JS (2006) Islet1 and Islet2 have equivalent abilities to promote motoneuron formation and to specify motoneuron subtype identity. Development 133:2137-2147. CrossRef Medline

Kim CH, Ueshima E, Muraoka O, Tanaka H, Yeo SY, Huh TL, Miki N (1996) Zebrafish elav/HuC homologue as a very early neuronal marker. Neurosci Lett 216:109-112. CrossRef Medline

Kim YK, Yu J, Han TS, Park SY, Namkoong B, Kim DH, Hur K, Yoo MW, Lee HJ, Yang HK, Kim VN (2009) Functional links between clustered microRNAs: suppression of cell-cycle inhibitors by microRNA clusters in gastric cancer. Nucleic Acids Res 37:1672-1681. CrossRef Medline

Kimmel CB, Ballard WW, Kimmel SR, Ullmann B, Schilling TF (1995) Stages of embryonic development of the zebrafish. Dev Dyn 203:253-310. CrossRef Medline

Korzh V, Edlund T, Thor S (1993) Zebrafish primary neurons initiate expression of the LIM homeodomain protein Isl- 1 at the end of gastrulation. Development 118:417-425. Medline

Kruman II, Wersto RP, Cardozo-Pelaez F, Smilenov L, Chan SL, Chrest FJ, Emokpae R Jr, Gorospe M, Mattson MP (2004) Cell cycle activation linked to neuronal cell death initiated by DNA damage. Neuron 41:549_ 561. CrossRef Medline

Kumar M, Lu Z, Takwi AA, Chen W, Callander NS, Ramos KS, Young KH, Li Y (2011) Negative regulation of the tumor suppressor p53 gene by microRNAs. Oncogene 30:843-853. CrossRef Medline

Laine H, Doetzlhofer A, Mantela J, Ylikoski J, Laiho M, Roussel MF, Segil N, Pirvola U (2007) p19(Ink4d) and p21(Cip1) collaborate to maintain the postmitotic state of auditory hair cells, their codeletion leading to DNA damage and p53-mediated apoptosis. J Neurosci 27:1434-1444. CrossRef Medline

Laine H, Sulg M, Kirjavainen A, Pirvola U (2010) Cell cycle regulation in the inner ear sensory epithelia: role of cyclin D1 and cyclin-dependent kinase inhibitors. Dev Biol 337:134-146. CrossRef Medline

Lee EY, Chang CY, Hu N, Wang YC, Lai CC, Herrup K, Lee WH, Bradley A (1992) Mice deficient for Rb are nonviable and show defects in neurogenesis and haematopoiesis. Nature 359:288-294. CrossRef Medline

Lewis KE, Eisen JS (2003) From cells to circuits: development of the zebrafish spinal cord. Prog Neurobiol 69:419-449. CrossRef Medline

Marín F, Nieto MA (2006) The expression of Scratch genes in the developing and adult brain. Dev Dyn 235:2586-2591. CrossRef Medline

Monteys AM, Spengler RM, Wan J, Tecedor L, Lennox KA, Xing Y, Davidson BL (2010) Structure and activity of putative intronic miRNA promoters. RNA 16:495-505. CrossRef Medline

Nakakura EK, Watkins DN, Schuebel KE, Sriuranpong V, Borges MW, Nel- 
kin BD, Ball DW (2001) Mammalian Scratch: a neural-specific Snail family transcriptional repressor. Proc Natl Acad Sci U S A 98:4010-4015. CrossRef Medline

Nasevicius A, Ekker SC (2000) Effective targeted gene 'knockdown' in zebrafish. Nat Genet 26:216-220. CrossRef Medline

Nieto MA (2011) The ins and outs of the epithelial to mesenchymal transition in health and disease. Annu Rev Cell Dev Biol 27:347-376. CrossRef Medline

Pajalunga D, Mazzola A, Salzano AM, Biferi MG, De Luca G, Crescenzi M (2007) Critical requirement for cell cycle inhibitors in sustaining nonproliferative states. J Cell Biol 176:807-818. CrossRef Medline

Park HC, Hong SK, Kim HS, Kim SH, Yoon EJ, Kim CH, Miki N, Huh TL (2000) Structural comparison of zebrafish Elav/Hu and their differential expressions during neurogenesis. Neurosci Lett 279:81-84. CrossRef Medline

Park HC, Boyce J, Shin J, Appel B (2005) Oligodendrocyte specification in zebrafish requires notch-regulated cyclin-dependent kinase inhibitor function. J Neurosci 25:6836-6844. CrossRef Medline

Petrocca F, Vecchione A, Croce CM (2008) Emerging role of miR-106b-25/ miR-17-92 clusters in the control of transforming growth factor beta signaling. Cancer Res 68:8191-8194. CrossRef Medline

Pfeffer PL, Gerster T, Lun K, Brand M, Busslinger M (1998) Characterization of three novel members of the zebrafish Pax $2 / 5 / 8$ family: dependency of Pax5 and Pax8 expression on the Pax2.1 (noi) function. Development 125:3063-3074. Medline

Roark M, Sturtevant MA, Emery J, Vaessin H, Grell E, Bier E (1995) scratch, a pan-neural gene encoding a zinc finger protein related to snail, promotes neuronal development. Genes Dev 9:2384-2398. CrossRef Medline

Robu ME, Larson JD, Nasevicius A, Beiraghi S, Brenner C, Farber SA, Ekker SC (2007) p53 activation by knockdown technologies. PLoS Genet 3:e78. CrossRef Medline

Rodríguez-Aznar E, Nieto MA (2011) Repression of Puma by scratch2 is required for neuronal survival during embryonic development. Cell Death Differ 18:1196-1207. CrossRef Medline

Sage J, Miller AL, Pérez-Mancera PA, Wysocki JM, Jacks T (2003) Acute mutation of retinoblastoma gene function is sufficient for cell cycle reentry. Nature 424:223-228. CrossRef Medline

Sikand K, Slane SD, Shukla GC (2009) Intrinsic expression of host genes and intronic miRNAs in prostate carcinoma cells. Cancer Cell Int 9:21. CrossRef Medline

Skapek SX, Lin SC, Jablonski MM, McKeller RN, Tan M, Hu N, Lee EY (2001) Persistent expression of cyclin D1 disrupts normal photoreceptor differentiation and retina development. Oncogene 20:6742-6751. CrossRef Medline

Spruce T, Pernaute B, Di-Gregorio A, Cobb BS, Merkenschlager M, Manzanares M, Rodriguez TA (2010) An early developmental role for miRNAs in the maintenance of extraembryonic stem cells in the mouse embryo. Dev Cell 19:207-219. CrossRef Medline

Tanzer A, Stadler PF (2004) Molecular evolution of a microRNA cluster. J Mol Biol 339:327-335. CrossRef Medline

Tury A, Mairet-Coello G, DiCicco-Bloom E (2011) The cyclin-dependent kinase inhibitor p57Kip2 regulates cell cycle exit, differentiation, and migration of embryonic cerebral cortical precursors. Cereb Cortex 21:1840-1856. CrossRef Medline

Varvel NH, Bhaskar K, Kounnas MZ, Wagner SL, Yang Y, Lamb BT, Herrup K (2009) NSAIDs prevent, but do not reverse, neuronal cell cycle reentry in a mouse model of Alzheimer disease. J Clin Invest 119:3692-3702. CrossRef Medline

Vega S, Morales AV, Ocaña OH, Valdés F, Fabregat I, Nieto MA (2004) Snail blocks the cell cycle and confers resistance to cell death. Genes Dev 18: 1131-1143. CrossRef Medline

Yan Y, Frisén J, Lee MH, Massagu é J, Barbacid M (1997) Ablation of the CDK inhibitor p57Kip2 results in increased apoptosis and delayed differentiation during mouse development. Genes Dev 11:973-983. CrossRef Medline

Zhang J, Cicero SA, Wang L, Romito-Digiacomo RR, Yang Y, Herrup K (2008) Nuclear localization of Cdk5 is a key determinant in the postmitotic state of neurons. Proc Natl Acad Sci U S A 105:8772-8777. CrossRef Medline

Zhang P, Liégeois NJ, Wong C, Finegold M, Hou H, Thompson JC, Silverman A, Harper JW, DePinho RA, Elledge SJ (1997) Altered cell differentiation and proliferation in mice lacking p57KIP2 indicates a role in Beckwith-Wiedemann syndrome. Nature 387:151-158. CrossRef Medline

Zupanc GK, Hinsch K, Gage FH (2005) Proliferation, migration, neuronal differentiation, and long-term survival of new cells in the adult zebrafish brain. J Comp Neurol 488:290-319. CrossRef Medline 